\title{
COMPARISON OF TWO METHODS FOR PURIFICATION OF PLANTARICIN ST31, A BACTERIOCIN PRODUCED BY LACTOBACILLUS PLANTARUM ST31
}

\author{
Svetoslav D. Todorov ${ }^{1 *}$; Manuela Vaz-Velho ${ }^{2,3}$; Paul Gibbs ${ }^{2,4}$

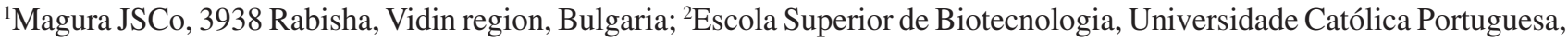 \\ Porto, Portugal; ${ }^{3}$ Escola Superior de Tecnologia e Gestão, Instituto Politécnico de Viana do Castelo, Portugal; ${ }^{4}$ Leatherhead \\ Food Research Association, Surrey, England
}

Submitted: July 22, 2003; Returned to authors: December 05, 2003; Approved: May 20, 2004.

\begin{abstract}
Two methods of purification of the plantaricin ST31, a bacteriocin produced by Lactobacillus plantarum ST31 are used in this study - the method of ammonium sulfate precipitation, Sep-pack $\mathrm{C}_{18}$ cartridge and reverse-phase HPLC chromatography on $\mathrm{C}_{18}$ Nucleosil column, and the method of direct purification by cation exchange SP Sepharose Fast Flow column Amersham (Pharmacia Biotech). The purity of the products from the two experimental protocols are examined for their molecular weight, aminoacid composition and sequence. Comparison of results show that the plantaricins purified with the two methods are identical. Both methods may be used to purify plantaricin ST31. Comparison of the yield in the purification protocols is $0.8 \%$ in the HPLC experimental protocol and 5.9\% in the cation-exchange chromatography method.
\end{abstract}

Key words: Lactobacillus plantarum, bacteriocin, plantaricin, HPLC, cation-exchange chromatography (IEX)

\section{INTRODUCTION}

Lactobacillus plantarum is important in many food fermentations either as a component of the natural microflora or when used as a starter culture. A number of L. plantarum strains produce bacteriocins, many of which have been isolated and partially characterized $(2,6,9,10,14,16)$.

Several methods have been reported for the purification of plantaricins: (a) anion-exchange chromatography (DEAESephadex A-25) and reverse-phase HPLC (9); (b) ammonium sulfate precipitation ( $80 \%$ ), cation-exchange chromatography (SP Sepharose fast-flow cation exchange column), hydrophobic interaction chromatography (phenyl-Sepharose CL-4B column) and $\mathrm{C}_{2} / \mathrm{C}_{18}$ reverse-phase chromatography (8); (c) ammonium sulfate precipitation $(55 \%)$, hydrophobic interaction $\left(\mathrm{C}_{8}\right)$, cation exchange chromatography Mono S cation-exchange column (Pharmacia, Biotech) (6); (d) ammonium sulfate precipitation (40\%) and cation exchange - SP-Sepharose (1); (e) ammonium sulfate precipitation (60\%), cation-exchange chromatography, hydrophobic interaction chromatography (11); (f) ammonium sulfate precipitation, cation exchange (S- Sepharose), reversedstationary-phase (octyl-sepharose - CL-4B), stationary-phase $\mathrm{C}_{2} / \mathrm{C}_{18}$ chromatography $(5,10)$ and $(\mathrm{g})$ ammonium sulfate

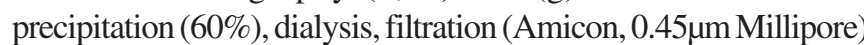
and ultrafiltration (4). A rapid and two-step procedure suitable for both small- and large-scale purification of pediocin-like bacteriocins and other cationic peptides have been reported (15). Bacterial cells and anionic compounds passed through the column, with cationic bacteriocins being eluted subsequently with $1 \mathrm{M} \mathrm{NaCl}$ (15). The method most commonly used is ammonium sulfate precipitation at different concentrations, followed by HPLC.

We described two methods for the purification of plantaricin ST31: (a) method of precipitation with ammonium sulfate, Seppack $\mathrm{C}_{18}$ cartridge and reverse-phase HPLC on a $\mathrm{C}_{18}$ Nucleosil column, and (b) a method of direct purification with SP Sepharose

*Corresponding author. Mailing address: Department of Microbiology, University of Stellenbosch. 7600 Stellenbosch, South Africa. Tel: (+2721) 8085850, Fax: (+2721) 8085846. E-mail: todorov@ sun.ac.za 
Fast Flow (Pharmacia Biotech). The homogenic nature of plantaricin ST31 purified by the second method was confirmed by reverse-phase HPLC on a $\mathrm{C}_{18}$ Nucleosil column.

\section{MATERIALS AND METHODS}

\section{Strains and media}

For cultivation of L. plantarum ST31, the producer strain and $L$. plantarum LAB 73, the sensitive strain, MRS broth and MRS agar (Merck, Darmstadt, Germany) (3) were used. Incubation was done at $30^{\circ} \mathrm{C}$ for $24 \mathrm{~h}$. Both strains have been isolated from fermented cereal products (14). The strains were stored at $-80^{\circ} \mathrm{C}$ in MRS broth containing $15 \%$ ( $\mathrm{vol} / \mathrm{vol}$ ) glycerol. Before use, the strains were cultivated twice for $24 \mathrm{~h}$ at $30^{\circ} \mathrm{C}$ in MRS broth.

\section{Bacteriocin activity assay}

Bacteriocin screening was performed by two methods, the agar spot test and the well diffusion method as described by Schillinger and Lücke (12) and Tagg and McGiven (13), respectively. Normally $1.5 \%$ agar was used. For overlay $1.0 \%$ soft agar was prepared. To eliminate the action of lactic acid on the test organisms, the $\mathrm{pH}$ of the supernatants was adjusted to 6.0 with sterile $1 \mathrm{~N} \mathrm{NaOH}$. The activity was expressed in arbitrary units (AU per ml). One AU was defined as the reciprocal of the highest serial two-fold dilution showing a clear zone of growth inhibition of the indicator strain.

\section{Production studies}

Tween-free MRS medium prepared from basal ingredients was sterilized by autoclaving $\left(15 \mathrm{~min}, 120^{\circ} \mathrm{C}\right)$ and was aseptically transferred to a bioreactor connected to an automatic $\mathrm{pH}$ and temperature controller (Set 2M; SGI, Toulouse, France). The medium was inoculated with $2 \%(\mathrm{vol} / \mathrm{vol})$ of an overnight grown culture of L. plantarum ST31. The $\mathrm{pH}$ was maintained at 6.0 with $6 \mathrm{M} \mathrm{NaOH}$. The temperature was controled at $30^{\circ} \mathrm{C}$, and agitation was set at $100 \mathrm{rpm}$. Samples were taken at different time intervals for determination of optical density at $600 \mathrm{~nm}$ and antimicrobial activity, as described before.

\section{Bacteriocin purification}

Method of Precipitation with Ammonium sulfate, Sep-pack $C_{18}$ cartridge and reverse-phase HPLC on a $C_{18}$ Nucleosil column. A 24-h-old culture ( $200 \mathrm{ml})$ of L. plantarum ST31 was centrifuged for $15 \mathrm{~min}$ at $20,000 \mathrm{xg}, 4^{\circ} \mathrm{C}$. The active supernatant was treated for $10 \mathrm{~min}$ at $80^{\circ} \mathrm{C}$ to prevent bacteriocin proteolysis. Ammonium sulfate (Kimax) was gently added to the cell supernatant (maintained at $4^{\circ} \mathrm{C}$ ) to obtain $60 \%$ saturation $(1,6)$, and stirred for $4 \mathrm{~h}$. After centrifugation ( $1 \mathrm{~h}$ at $20,000 \times \mathrm{g}, 4^{\circ} \mathrm{C}$ ), the pellet was resuspended in $25 \mathrm{mM}$ ammonium acetate ( $\mathrm{pH}$ 6.5) and loaded on a Sep-Pack $\mathrm{C}_{18}$ cartridge (Waters Millipore, MA, USA). The cartridge was washed with $20 \%$ i-propanol in $25 \mathrm{mM}$ ammonium acetate ( $\mathrm{pH} 6.5$ ) and the bacteriocin was eluted with $40 \%$ i-propanol in $25 \mathrm{mM}$ ammonium acetate (pH 6.5). After drying under reduced pressure (Speed-Vac; Savant, France), the fractions were partially dissolved in $0.1 \%$ trifluoracetic acid (TFA) and tested for antimicrobial activity. This active fraction was further purified by reverse-phase HPLC on a C18 Nucleosil column $(250 \times 4.6 \mathrm{~mm})$. Elution was performed by applying a linear gradient from $0.1 \%$ TFA (solvent A) to $90 \%$ acetonitrile in $0.1 \%$ TFA (solvent B) in 65 min. Polypeptides, detected by $\mathrm{A}_{220}$, were collected manually. After drying under reduced pressure and resuspension in $1 \mathrm{ml}$ of de-ionised water, the aqueous polypeptide solutions were stored at $-20^{\circ} \mathrm{C}$.

Method of direct purification with cation exchange chromatography by using a SP Sepharose Fast Flow column (Amersham, Pharmacia Biotech). A24-h-old culture $(200 \mathrm{ml})$ of L. plantarum ST31 was centrifuged for $15 \mathrm{~min}$ at $20,000 \mathrm{xg}, 4^{\circ} \mathrm{C}$. The active supernatant was treated for $10 \mathrm{~min}$ at $80^{\circ} \mathrm{C}$ to prevent bacteriocin proteolysis.

This supernatant was used for purification by cation exchange column [SP Sepharose Fast Flow (Amersham, Pharmacia Biotech)]. Elution was performed by using a linear gradient from $100 \% 25 \mathrm{mM}$ ammonium acetate buffer $\mathrm{pH} 6.5$ (buffer A) in 0 min to $100 \% 1 \mathrm{M} \mathrm{NaCl}$ (buffer B) in $20 \mathrm{~min}, 100 \%$ buffer B in 25 min and $100 \%$ buffer A in 30 min by FPLC system, flow rate $5 \mathrm{ml} / \mathrm{min}$. Polypeptides, detected by $\mathrm{A}_{220}$, were collected manually. The collected polypeptides were tested for activity against the target strain, L. plantarum LAB 73.

The active fraction was subjected to reverse-phase HPLC, according to the previously described method. Protein content (in milligrams per millilitre), estimated by the Bradford method, and antimicrobial activity were determined at each step of the purification process.

\section{Mass spectrometry}

Active peptide fractions collected from HPLC was subjected to electrospray mass spectrometry (ESMS). ESMS was done on a VG Bio-Q quadrupole with a mass range of $4000 \mathrm{Da}$ (Bio-Tech, Manchester, UK) in the positive mode. The protein was dissolved in $\mathrm{H}_{2} \mathrm{O} / \mathrm{CH}_{3} \mathrm{CN}(50 / 50, \mathrm{v} / \mathrm{v})$ with $1 \%$ acid at a concentration of about $5 \mathrm{pmol} / \mu \mathrm{l}$ (by volume); $10-\mu \mathrm{l}$ aliquots were introduced into the ion-source at a flow rate of $4 \mu \mathrm{l} / \mathrm{min}$. Scanning was usually performed from $\mathrm{m} / z=500$ to $\mathrm{m} / z=1,500$ in $10 \mathrm{~s}$ with the resolution adjusted so that the peak at $m / z=998$ from horse heart myoglobin was $1.5-2$ wide on the base. Calibration was performed by using the multiply charged ions produced by separate introduction of horse heart myoglobin (16,950.4 Da) (7).

\section{RESULTS AND DISCUSSION}

Purification by precipitation with ammonium sulfate, Seppack $C_{18}$ cartridge and reverse-phase HPLC on a $C_{18}$ Nucleosil column. Since the maximum activity was found in the culture 
medium at the beginning of the stationary phase, the bacteriocin was isolated from 24-h-old cultures in MRS medium at $\mathrm{pH}$ 6.0. The bacteriocin was pre-purified by ammonium sulfate precipitation. The recovery was approximately $40 \%$. The precipitate was subjected to filtration on a Sep-Pack $\mathrm{C}_{18}$ cartridge. The active fraction was eluted with $40 \%$ iso-propanol. At this stage of purification, the recovery was $4 \%$ and the specific activity increased approximately $1.9 \times 10^{3}$-fold. Separation of the active fraction on a HPLC $\mathrm{C}_{18}$ reversephase column yielded an active peak which eluted at $38.08 \mathrm{~min}$. (data not shown). At this stage the purification factor reached $1.2 \times 10^{4}$-fold and the recovery was $0.8 \%$ (Table 1 ). The active fraction was purified by subsequent reverse-phase chromatography and its amino acid sequence determined. The peptide consists of 20 amino acids with a total mass of 2,755.63 Da, as estimated by mass spectrometry. The sequence was determined to be: Lys-Arg-Lys-Lys-His-Arg-XaaGly-Val-Tyr-Asn-Asn-Gly-Met-Pro-Thr-Gly-Met-TyrArg.

A second active peak, which eluted at $36.62 \mathrm{~min}$, was also recorded (data not shown). The protein recovery was identical to that recorded for that eluted at $38.08 \mathrm{~min}$. The molecular mass of the peptide was 2,771.58 Da. Analysis of the amino acid sequence revealed primary structure similar to that of the 2,755.63 Da peptide, but with oxygenated methionine.

Purification with a cation exchange SP Sepharose Fast Flow column (Amersham, Pharmacia Biotech). For the purification, an active supernatant from the same fermentation flask of the previous experiment was used. The active supernatant was subjected to cation-exchange chromatography (SPSepharose, Amersham, Pharmacia Biotech). The active fraction was eluted with $100 \%$ buffer $\mathrm{B}-1 \mathrm{M} \mathrm{NaCl}$ after 20 min from the beginning of the gradient (data not shown). At this stage of purification, the recovery was $5.94 \%$ and the specific activity increased approximately $1.1 \times 10^{2}$-fold (Table 2). Further separation by HPLC on $\mathrm{C}_{18}$ reversed-phase column, yielded an active peak which eluted at $63.71 \mathrm{~min}$. (data not shown). The active fraction was purified by reverse-phase chromatography and its amino acid sequence determined. Mass spectrometry of the active peptide corresponded to that recorded for plantaricin ST31, as purified by the previously described method. The amino acid composition was also identical to previously described.

Discussion. Comparison of the two methods revealed that separation by HPLC is more expensive and tedious. Compared to the HPLC method, the utilisation of cation-exchange chromatography is less expensive, and more rapid. Furthermore, half of the plantaricin ST31 purified by HPLC is converted into an oxygenated form. This phenomenon reduced the yield of plantaricin ST31 by $50 \%$.
Table 1. Purification of plantaricin ST31 by precipitation with ammonium sulfate, Sep-pack $\mathrm{C}_{18}$ cartridge and reverse-phase HPLC on a $\mathrm{C}_{18}$ Nucleosil column.

\begin{tabular}{cccccc}
\hline $\begin{array}{c}\text { Sample } \\
(\mathrm{ml})\end{array}$ & $\begin{array}{c}\text { Total } \\
\text { activity } \\
(\mathrm{AU})\end{array}$ & $\begin{array}{c}\text { Protein } \\
(\mathrm{mg})\end{array}$ & $\begin{array}{c}\text { Specific } \\
\text { activity } \\
(\mathrm{AU} / \mathrm{mg})\end{array}$ & $\begin{array}{c}\text { Yield } \\
(\%)\end{array}$ & $\begin{array}{c}\text { Purification } \\
\text { factor }\end{array}$ \\
\hline $\begin{array}{c}\text { Supernatant / 200 } \\
\begin{array}{c}\text { Ammonium sulfate } \\
\text { precipitation/20 }\end{array}\end{array}$ & $6.4 \times 10^{5}$ & 1810 & $3.5 \times 10^{2}$ & 100 & 1 \\
$\begin{array}{c}\text { SepPack 40\% } \\
\text { isopropanol / } 2\end{array}$ & $2.5 \times 10^{5}$ & 10.6 & $2.4 \times 10^{4}$ & 40 & $6.9 \times 10^{1}$ \\
${\text { HPLC } \mathrm{C}_{18} / 0.2}^{\text {Hep }}$ & $5.1 \times 10^{3}$ & 0.001 & $5.1 \times 10^{6}$ & 0.8 & $1.2 \times 10^{4}$ \\
\hline
\end{tabular}

Table 2. Purification of plantaricin ST31 by SP Sepharose Fast Flow (Pharmacia Biotech) Chromatography.

\begin{tabular}{cccccc}
$\begin{array}{c}\text { Sample } \\
(\mathrm{ml})\end{array}$ & $\begin{array}{c}\text { Total } \\
\text { activity } \\
(\mathrm{AU})\end{array}$ & $\begin{array}{c}\text { Protein } \\
(\mathrm{mg})\end{array}$ & $\begin{array}{c}\text { Specific } \\
\text { activity } \\
(\mathrm{AU} / \mathrm{mg})\end{array}$ & $\begin{array}{c}\text { Yield } \\
(\%)\end{array}$ & $\begin{array}{c}\text { Purification } \\
\text { factor }\end{array}$ \\
\hline $\begin{array}{c}\text { Supernatant/200 } \\
\text { SP Sepharose Fast }\end{array}$ & $6.4 \times 10^{5}$ & 1810 & $3.5 \times 10^{2}$ & 100 & 1 \\
Flow column/30 & $3.8 \times 10^{4}$ & 0.96 & $3.9 \times 10^{4}$ & 5.94 & $1.1 \times 10^{2}$ \\
\hline
\end{tabular}

The differences in the results of the purification of plantaricin ST31 and the yield in the first and second experimental protocols ( $0.8 \%$ by HPLC and $5.94 \%$ by cation-exchange chromatography) might be explained by the longer HPLC experimental procedure and the different treatments of the supernatant.

Precipitation with ammonium sulfate was not required prior to cation-exchange, as reported by other authors $(1,5,8,10,11)$.

The molecular mass obtained for plantaricin ST31 by using the two methods was identical when the oxygenated form of methionine is taken into account (MM: $2771.58+/-0.11$ and MM: $2763.32+/-0.11$, respectively).

From these results, we can conclude that Lactobacillus plantarum ST31 produces one form of plantaricin ST31. The existence of two active forms of plantaricin ST31 (with oxygenated and non-oxygenated at methionine) suggests methionine is not present in the part of the molecule responsible for the bacteriocin activity.

\section{ACKNOWLEDGMENTS}

This work was supported by the Culture Service of the French Embassy in Sofia, Bulgaria. 


\section{RESUMO}

\section{Comparação de dois métodos de purificação da plantaricina ST31, a bacteriocina produzida por Lactobacillus plantarum ST31}

Dois métodos de purificação de plantaricin ST31, uma bacteriocina produzida por Lactobacillus plantarum ST31 foram usados neste estudo - o método de precipitação pelo sulfato de amônia usando cartucho Sep-pack C18 para a filtração e HPLC de fase reversa em coluna de C18 Nucleosil, e o método de purificação direta por troca catiônica SP Sepharose "Fast Flow column Amersham" (Pharmacia Biotech). A pureza dos produtos obtidos pelos dois protocolos foi examinada através da determinação dos pesos moleculares, composição e sequiência dos aminoácidos. A comparação destes resultados revelou que, em termos da pureza dos produtos, não havia diferenças entre os dois métodos de purificação podendo-se, portanto, utilizar qualquer um dos protocolos de purificação testados. No entanto, o rendimento da purificação pelo método da troca catiônica foi de $5.9 \%$ enquanto o do método HPLC foi de $0.8 \%$.

Palavras-chave: Lactobacillus plantarum, bacteriocina, plantaricina, HPLC, cromatografia por troca catiônica (IEX)

\section{REFERENCES}

1. Anderssen, E.L.; Diep, D.B.; Nes, I.F.; Eijsink, V.G.H.; Nissen-Meyer, J. Antagonistic activity of Lactobacillus plantarum C11: two new two-peptide bacteriocins, plantaricin EF and JK, and the induction factor plantaricin A. Appl. Environ. Microbiol., 64:2269-2272, 1998.

2. Daeschel, M.A.; McKenny. M.C.; McDonald, L.C. Bacteriocidal activity of Lactobacillus plantarum C11. Food Microbiol., 7:9199, 1990.

3. De Man, J.C.; Rogosa, M.; Sharpe. E. A medium for the cultivation of Lactobacilli. J. Appl. Bacteriol., 23:130-135, 1960.

4. Enan, G.; Essaway, A.A.; Uyttendaele, M.; Debevere, J. Antibacterial activity of Lactobacillus plantarum UG1 isolated from dry sausage: characterization, production and bactericidal activity of plantaricin UG1. Int. J. Food Microbiol., 30:189-215, 1996.

5. Ennahar, S.; Aoude-Werner, D.; Sorokine, O.; Van Dorsselaer, A.; Bringel, F.; Hubert, J.C.; Hasselmann, C. Production of plantaricin $\mathrm{AcH}$ by Lactobacillus plantarum WHE 92, isolated from cheese. Appl. Environ. Microbiol., 62:4381-4387, 1996.

6. Gonzalez, B.; Arca, P.; Mayo, B.; Suarez, J. Detection, purification and partial characterization of plantaricin $\mathrm{C}$, a bacteriocin produced by a Lactobacillus plantarum strain of dairy origin. Appl. Environ. Microbiol., 6:2158-2163, 1994.

7. Jaquinod, M.; Pottier, N.; Klarskov, K.; Reymann, J.M.; Sorokine, O.; Kieffer, S.; Barth, P.; Andriantomanga, V.; Bielmann, J.F.; Dorsselaer, V. Sequence of pig lens aldose reductase and electrospray mass spectrometry of non-covalent and covalent complex. Eur. J. Biochem., 218:893-903, 1993.

8. Jimenez-Diaz, R.; Rios-Sanchez, R.M.; Desmazeaud, M.; Ruiz-Barrba J.L.; Piard. J.-C. Plantaricin S and T, two new bacteriocins produced by Lactobacillus plantarum LPCO10 isolated from a green olive fermentation. Appl. Environ. Microbiol., 59:1416-1424, 1995.

9. Kato, T.; Matsuda, T.; Ogawa, E.; Ogawa, H.; Kato, H.; Doi, U.; Nakamura R. Plantaricin 149, a bacteriocin produced by Lactobacillus plantarum NRIC 149. J. Ferment Bioeng., 77:277-282, 1994.

10. Nissen-Meyer, A.; Laesen, G.; Sletten, K.; Daeschel, M.A.; Nes, I.F. Purification and characterization of plantaricin A, a Lactobacillus plantarum bacteriocin whose activity depends on the action of two peptides. J. Gen. Microbiol., 139:1973-1978, 1993.

11. Rekhif, N.; Atrih, A.; Michel, M.; Lefebvre, G. Activity of plantaricin SA6, a bacteriocin produced by Lactobacillus plantarum SA6 isolated from fermented sausage. J. Appl. Bacteriol., 78:349-358, 1995.

12. Schillinger, U.; Lucke, F.K. Antibacterial activity of Lactobacillus sake isolated from meat. J. Appl. Bacteriol., 70:473-478, 1989.

13. Tagg, J.R.; McGiven, A.R. Assay system for bacteriocins. Appl. Microbiol., 21:943, 1971.

14. Todorov, S.; Onno, B.; Sorokine, O.; Chobert, J.M.; Ivanova, I.; Dousset, X. Detection and characterization of a novel antibacterial substance produced by Lactobacillus plantarum ST31 isolated from sourdough. Int. J. Food Microbiol., 48:167-177, 1999.

15. Uteng, M.; Hauge, H.H.; Brondz, I.; Nissen-Meyer, J.; Fimland, G. Rapid two-step procedure for large-scale purification of pediocin-like bacteriocins and other cationic antimicrobial peptides from complex culture medium. Appl. Environ. Microbiol., 68:952-956, 2002.

16. Van Reenen, C.A.; Dicks, L.M.T.; Chikindas, M.L. Isolation, purification and partial characterization of plantaricin 423, a bacteriocin produced by Lactobacillus plantarum. J. Appl. Microbiol., 84:1131-1137, 1998. 